\title{
Modelling of simultaneous nitrogen and thiocyanate removal through coupling thiocyanate-based denitrification with anaerobic ammonium oxidation
}

Chen, Xueming; Yang, Linyan; Sun, Jing; Dai, Xiaohu; Ni, Bing-Jie

Published in:

Environmental Pollution

Link to article, DOI:

10.1016/j.envpol.2019.07.104

Publication date:

2019

Document Version

Peer reviewed version

Link back to DTU Orbit

Citation (APA):

Chen, X., Yang, L., Sun, J., Dai, X., \& Ni, B-J. (2019). Modelling of simultaneous nitrogen and thiocyanate removal through coupling thiocyanate-based denitrification with anaerobic ammonium oxidation. Environmental Pollution, 253, 974-980. https://doi.org/10.1016/j.envpol.2019.07.104

\section{General rights}

Copyright and moral rights for the publications made accessible in the public portal are retained by the authors and/or other copyright owners and it is a condition of accessing publications that users recognise and abide by the legal requirements associated with these rights.

- Users may download and print one copy of any publication from the public portal for the purpose of private study or research.

- You may not further distribute the material or use it for any profit-making activity or commercial gain

- You may freely distribute the URL identifying the publication in the public portal 


\section{Accepted Manuscript}

Modelling of simultaneous nitrogen and thiocyanate removal through coupling thiocyanate-based denitrification with anaerobic ammonium oxidation

Xueming Chen, Linyan Yang, Jing Sun, Xiaohu Dai, Bing-Jie Ni

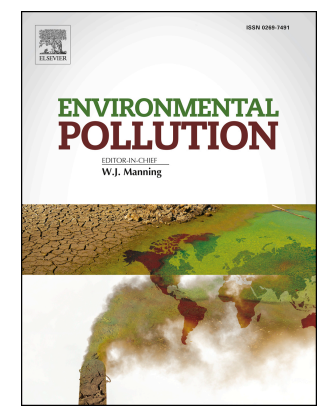

PII:

S0269-7491(19)31482-4

DOI: https://doi.org/10.1016/j.envpol.2019.07.104

Reference: $\quad$ ENPO 12936

To appear in: Environmental Pollution

Received Date: 21 March 2019

Revised Date: 19 July 2019

Accepted Date: 19 July 2019

Please cite this article as: Chen, X., Yang, L., Sun, J., Dai, X., Ni, B.-J., Modelling of simultaneous nitrogen and thiocyanate removal through coupling thiocyanate-based denitrification with anaerobic ammonium oxidation, Environmental Pollution (2019), doi: https://doi.org/10.1016/j.envpol.2019.07.104.

This is a PDF file of an unedited manuscript that has been accepted for publication. As a service to our customers we are providing this early version of the manuscript. The manuscript will undergo copyediting, typesetting, and review of the resulting proof before it is published in its final form. Please note that during the production process errors may be discovered which could affect the content, and all legal disclaimers that apply to the journal pertain. 


\section{Graphical Abstract}

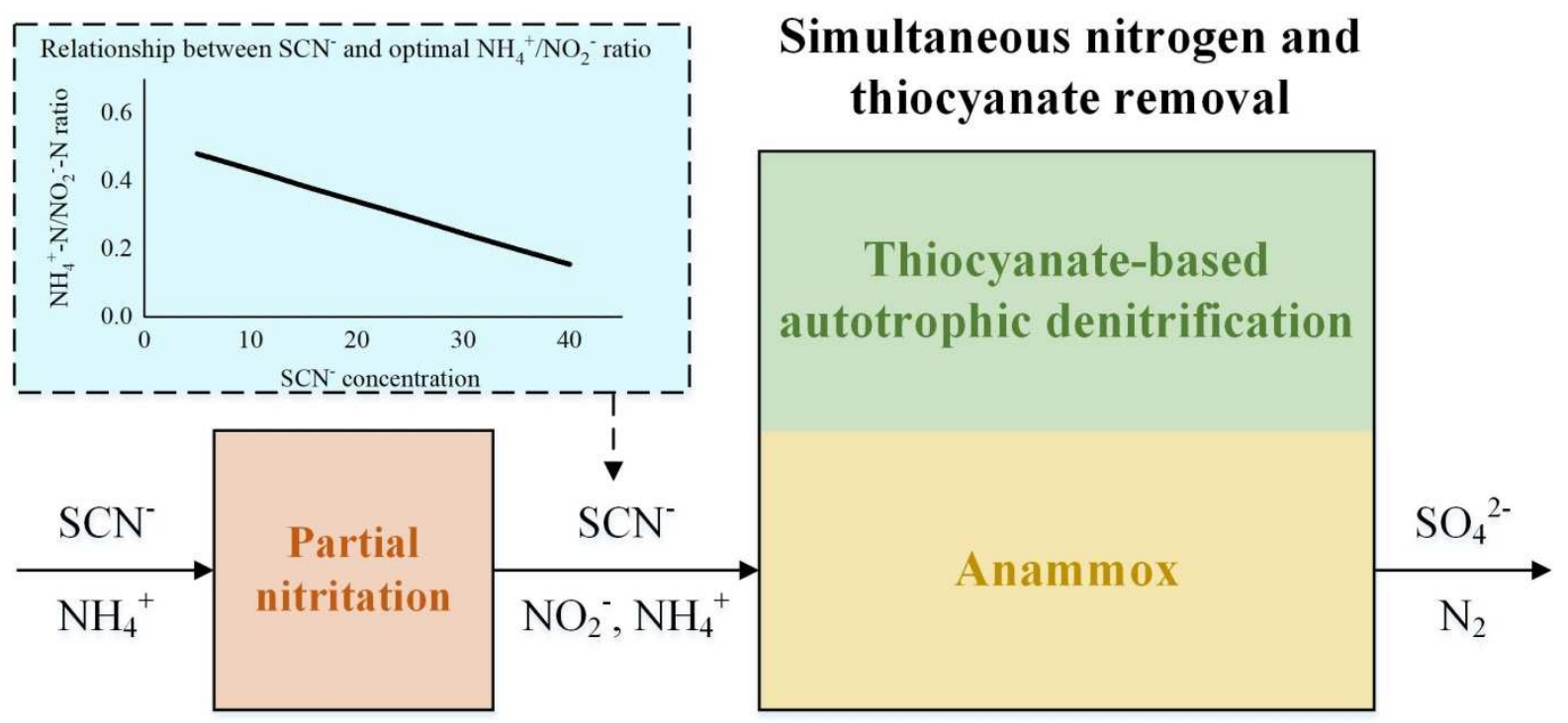




\section{ACCEPTED MANUSCRIPT}

1

2

3

4

5

$6{ }^{1}$ Process and Systems Engineering Center (PROSYS), Department of Chemical and

7 Biochemical Engineering, Technical University of Denmark, 2800 Kgs. Lyngby, Denmark

$8 \quad{ }^{2}$ School of Resources and Environmental Engineering, East China University of Science and

9 Technology, Shanghai 200237, China

$10{ }^{3}$ State Key Laboratory of Pollution Control and Resources Reuse, College of Environmental

11 Science and Engineering, Tongji University, Shanghai 200092, PR China

$12{ }^{4}$ Shanghai Institute of Pollution Control and Ecological Security, Shanghai200092, P.R.

13 China

14

$15 *$ Corresponding author:

16

Dr. Bing-Jie Ni, Phone: +86 216598 6849, E-mail: bjni@tongji.edu.cn 


\section{ABSTRACT}

Thiocyanate $\left(\mathrm{SCN}^{-}\right)$-based autotrophic denitrification $(\mathrm{AD})$ has recently been demonstrated as a promising technology that could be integrated with anaerobic ammonium oxidation (Anammox) to achieve simultaneous removal of nitrogen and $\mathrm{SCN}^{-}$. However, there is still a lack of a complete $\mathrm{SCN}^{-}$-based $\mathrm{AD}$ model, and the potential microbial competition/synergy between $\mathrm{AD}$ bacteria and Anammox bacteria under different operating conditions remains unknown, which significantly hinders the possible application of the coupling $\mathrm{SCN}^{-}$-based $\mathrm{AD}$ with Anammox. To this end, a complete $\mathrm{SCN}^{-}$-based $\mathrm{AD}$ model was firstly developed and reliably calibrated/validated using experimental datasets. The obtained $\mathrm{SCN}^{-}$-based $\mathrm{AD}$ model was then integrated with the well-established Anammox model and satisfactorily verified with experimental data from a system coupling AD with Anammox. The integrated model was lastly applied to investigate the impacts of influent $\mathrm{NH}_{4}{ }^{+}-\mathrm{N} / \mathrm{NO}_{2}{ }^{-}-\mathrm{N}$ ratio and $\mathrm{SCN}^{-}$concentration on the steady-state microbial composition as well as the removal of nitrogen and $\mathrm{SCN}^{-}$. The results showed that the $\mathrm{NH}_{4}{ }^{+}-\mathrm{N}^{-} \mathrm{NO}_{2}{ }^{-} \mathrm{N}$ ratio in the presence of a certain $\mathrm{SCN}^{-}$level should be controlled at a proper value so that the maximum synergy between $\mathrm{AD}$ bacteria and Anammox bacteria could be achieved while their competition for $\mathrm{NO}_{2}^{-}$would be minimized. For the simultaneous maximum removal (>95\%) of nitrogen and $\mathrm{SCN}^{-}$, there existed a negative relationship between the influent $\mathrm{SCN}^{-}$concentration and the optimal $\mathrm{NH}_{4}{ }^{+}-\mathrm{N} / \mathrm{NO}_{2}-\mathrm{N}$ ratio needed.

Capsule: High-level (>95\%) simultaneous removal of nitrogen and thiocyanate could be achieved through combining thiocyanate-based autotrophic denitrification and Anammox.

Keywords: thiocyanate-based autotrophic denitrification; anaerobic ammonium oxidation; microbial competition; synergy; modelling 


\section{INTRODUCTION}

Thiocyanate $\left(\mathrm{SCN}^{-}\right)$is a moderately toxic and chemically stable contaminant commonly found in the wastewaters of coking, plastic manufacturing, and gold mining industries (Gould et al., 2012; Kim et al., 2008; Pan et al., 2019; Sorokin et al., 2001). The direct discharge of wastewaters polluted with $\mathrm{SCN}^{-}$would therefore represent a significant threat to aquatic species (Bhunia et al., 2000) as well as human beings (Erdoğan, 2003). Compared to chemical destruction approaches, biological degradation of $\mathrm{SCN}^{-}$stands distinct advantages in terms of cost-effectiveness, removal efficiency, and production of secondary pollution (Felföldi et al., 2010; Gould et al., 2012). Both aerobic and anoxic technologies for biological $\mathrm{SCN}^{-}$degradation ultimately produce ammonium $\left(\mathrm{NH}_{4}{ }^{+}\right)$, sulfate $\left(\mathrm{SO}_{4}{ }^{2-}\right)$, and carbon dioxide $\left(\mathrm{CO}_{2}\right)$ (Broman et al., 2017; Kim et al., 2011; Pan et al., 2018a; Pan et al., 2018b; Staib and Lant, 2007). Nevertheless, anoxic autotrophic degradation of $\mathrm{SCN}^{-}$with oxidized nitrogenous species (such as nitrate $\left(\mathrm{NO}_{3}{ }^{-}\right)$in Eq. 1 or/and nitrite $\left(\mathrm{NO}_{2}^{-}\right)$in Eq. 2) as the electron acceptor, which has been demonstrated experimentally (Pan et al., 2018a; Pan et al., 2018b), is superior to aerobic autotrophic degradation of $\mathrm{SCN}^{-}$(Eq. 3), because it not only achieves denitrification but also requires no external energy input in the form of aeration. More importantly, the capability of the functional autotrophic denitrifying bacteria to respire on both $\mathrm{NO}_{3}^{-}$and $\mathrm{NO}_{2}^{-}$and the accompanying production of $\mathrm{NH}_{4}{ }^{+}$create the possibility of coupling $\mathrm{SCN}^{-}$-based autotrophic denitrification (AD) with anaerobic ammonium oxidation (Anammox). Anammox converts $\mathrm{NO}_{2}^{-}$and $\mathrm{NH}_{4}{ }^{+}$to nitrogen gas with lesser concomitant production of $\mathrm{NO}_{3}{ }^{-}$under autotrophic conditions and has been regarded as one of the most efficient and economical approaches for removing nitrogen from wastewater.

$5 \mathrm{SCN}^{-}+8 \mathrm{NO}_{3}{ }^{-} \rightarrow 5 \mathrm{SO}_{4}{ }^{2-}+5 \mathrm{NH}_{4}{ }^{+}+4 \mathrm{~N}_{2}+5 \mathrm{HCO}_{3}{ }^{-}+3 \mathrm{OH}^{-}$

$3 \mathrm{SCN}^{-}+8 \mathrm{NO}_{2}^{-}+2 \mathrm{H}_{2} \mathrm{O}+8 \mathrm{H}^{+} \rightarrow 3 \mathrm{SO}_{4}{ }^{2-}+3 \mathrm{NH}_{4}{ }^{+}+3 \mathrm{CO}_{2}+4 \mathrm{~N}_{2}$

$\mathrm{SCN}^{-}+2 \mathrm{O}_{2}+2 \mathrm{H}_{2} \mathrm{O} \rightarrow \mathrm{SO}_{4}^{2-}+\mathrm{NH}_{4}^{+}+\mathrm{CO}_{2}$ 
A suitable mixture of $\mathrm{NH}_{4}^{+}, \mathrm{NO}_{2}^{-}$, and $\mathrm{SCN}^{-}$is key for simultaneous removal of various contaminants when coupling $\mathrm{SCN}^{-}$-based AD with Anammox (Pan et al., 2019). In such a coupling system as presented in Figure 1, AD bacteria would compete with Anammox bacteria for $\mathrm{NO}_{2}{ }^{-}$, while $\mathrm{AD}$ bacteria and Anammox bacteria could also work synergistically to enhance nitrogen removal through cross-feeding interactions. Therefore, the ratio between $\mathrm{NH}_{4}{ }^{+}$and $\mathrm{NO}_{2}{ }^{-}$(i.e., $\mathrm{NH}_{4}{ }^{+}-\mathrm{N} / \mathrm{NO}_{2}{ }^{-}-\mathrm{N}$ ) for coupling $\mathrm{SCN}^{-}$-based $\mathrm{AD}$ with Anammox in the presence of $\mathrm{SCN}^{-}$, which could normally be regulated by the prepositioned partial nitritation process, should be significantly different from that for Anammox alone. Although Pan et al. (2019) studied the short-term division of labor between AD bacteria and Anammox bacteria under different initial conditions of $\mathrm{NO}_{2}{ }^{-}, \mathrm{NH}_{4}{ }^{+}$, and $\mathrm{SCN}^{-}$in batch mode, the long-term impacts of feeding $\mathrm{NO}_{2}{ }^{-}, \mathrm{NH}_{4}{ }^{+}$, and $\mathrm{SCN}^{-}$conditions on the microbial competition/synergy in the system coupling $\mathrm{SCN}^{-}$-based $\mathrm{AD}$ with Anammox are yet to be investigated. The existence of intermediate elemental sulfur (S) in the conversion of $\mathrm{SCN}^{-}$to $\mathrm{SO}_{4}{ }^{2-}$ and the sequential denitrification process receiving electrons from $\mathrm{SCN}^{-}$oxidation (see Figure 1), as observed experimentally by Pan et al. (2018b), further complicate the application of coupling $\mathrm{SCN}^{-}$based AD with Anammox. A reliable feasibility assessment of coupling $\mathrm{SCN}^{-}$-based $\mathrm{AD}$ with Anammox should take into account these relevant processes as well as associated key intermediates comprehensively. In this regard, mathematical modelling serves as a useful tool. Although the Anammox model is readily available, a complete $\mathrm{SCN}^{-}$-based $\mathrm{AD}$ model which covers the relevant pathways shown in Figure 1 has not been documented.

To this end, a complete $\mathrm{SCN}^{-}$-based $\mathrm{AD}$ model was firstly developed, calibrated, and validated in this work, which was then integrated with the well-established Anammox model and verified using literature reported experimental datasets. The integrated model was used to 
93 evaluate the feasibility of coupling $\mathrm{SCN}^{-}$-based $\mathrm{AD}$ with Anammox in a biofilm reactor,

94 focusing on the impacts of feeding $\mathrm{NH}_{4}{ }^{+}-\mathrm{N} / \mathrm{NO}_{2}{ }^{-}-\mathrm{N}$ ratio and $\mathrm{SCN}^{-}$concentration on the

microbial composition of the biofilm as well as the removal of nitrogen and $\mathrm{SCN}^{-}$. This work is expected to benefit the potential practical design and application of coupling $\mathrm{SCN}^{-}$-based $\mathrm{AD}$ with Anammox in the treatment of wastewater that contains $\mathrm{SCN}^{-}$and $\mathrm{NH}_{4}{ }^{+}$.

\section{MATERIALS AND METHODS}

\subsection{Experimental Datasets for Model Evaluations}

As listed in Table 1, eight series of literature reported experimental datasets were used in this work for model calibration and validation.

Datasets 1-1 to 1-3 (Pan et al., 2018a) containing the time-series profiles of $\mathrm{NO}_{2}^{-}, \mathrm{SCN}^{-}$, $\mathrm{NH}_{4}{ }^{+}$, and $\mathrm{SO}_{4}{ }^{2-}$ were obtained from batch tests carried out at the initial total nitrogen (TN, i.e., sum of $\mathrm{NO}_{2}^{-}$and $\mathrm{SCN}^{-}$) concentration of 100,200 , and $300 \mathrm{~g}-\mathrm{N} / \mathrm{m}^{3}$, respectively, with a fixed $\mathrm{NO}_{2}{ }^{-} \mathrm{N} / \mathrm{SCN}^{-}-\mathrm{N}$ ratio of 3.0. The mixed liquor suspended solid (MLSS) concentration was $1000 \mathrm{~g} / \mathrm{m}^{3}$, with the identified functional AD species (i.e., Thiobacillus) accounting for $38 \%$ of the denitrifying biomass. The dissolved oxygen (DO) concentration was controlled below $0.3 \mathrm{~g} / \mathrm{m}^{3}$, and the temperature was kept at $25 \square$.

Datasets 2-1 to 2-4 (Pan et al., 2018b) containing the time-series profiles of $\mathrm{NO}_{3}^{-}, \mathrm{NO}_{2}^{-}$, $\mathrm{SCN}^{-}, \mathrm{NH}_{4}{ }^{+}$, and $\mathrm{SO}_{4}{ }^{2-}$ were obtained from batch tests performed at the initial $\mathrm{NO}_{3}{ }^{-} \mathrm{N} / \mathrm{SCN}^{-}-$ $\mathrm{N}$ ratio of 1.0, 1.5, 2.0, and 3.0, respectively, with a fixed $\mathrm{TN}$ (i.e., sum of $\mathrm{NO}_{3}{ }^{-}$and $\mathrm{SCN}^{-}$) concentration of $100 \mathrm{~g}-\mathrm{N} / \mathrm{m}^{3}$. The MLSS concentration was $500 \mathrm{~g} / \mathrm{m}^{3}$, with the identified functional $\mathrm{AD}$ species (i.e., Thiobacillus) taking up $64.8 \%$ of the denitrifying biomass. Oxygen was removed by purging nitrogen gas, and the temperature was kept at $35 \square$. 
Dataset 3 (Pan et al., 2019) containing the time-series profiles of $\mathrm{NO}_{3}^{-}, \mathrm{NO}_{2}^{-}, \mathrm{SCN}^{-}$, and

$\mathrm{NH}_{4}{ }^{+}$was obtained from a batch test carried out at the initial $\mathrm{NO}_{2}^{-}$concentration of $75 \mathrm{~g}-$

$\mathrm{N} / \mathrm{m}^{3}$ and $\mathrm{SCN}^{-}$concentration of $25 \mathrm{~g}-\mathrm{N} / \mathrm{m}^{3}$. On top of the functional AD species (i.e.,

Thiobacillus) which occupied $38 \%$ of the denitrifying biomass at the MLSS concentration of $350 \mathrm{~g} / \mathrm{m}^{3}$, Anammox bacteria were added at the MLSS concentration of $1400 \mathrm{~g} / \mathrm{m}^{3}$ with the functional species (i.e., Candidatus kuenenia) identified at a relative abundance of $14.4 \%$. The DO concentration was controlled below $0.3 \mathrm{~g} / \mathrm{m}^{3}$, and the temperature was kept at $30 \square$.

\subsection{Development of Thiocyanate-Based AD Model}

The $\mathrm{SCN}^{-}$-based $\mathrm{AD}$ model was constructed based on the pathways as presented in Figure 1. Specifically, sulfur in $\mathrm{SCN}^{-}$is firstly oxidized to elemental sulfur and further to $\mathrm{SO}_{4}{ }^{2-}$, consistent with $\mathrm{Xu}$ et al. (2015), Xu et al. (2016), and Yang et al. (2016) who reported elemental sulfur as the intermediate in the biological oxidation of $\mathrm{S}^{2-}$ to $\mathrm{SO}_{4}{ }^{2-}$. The possible roles of $\mathrm{SCN}^{-}$and sulfite are not included in the model as they were not detected in the reported $\mathrm{SCN}^{-}$-based AD systems (Pan et al., 2018a; Pan et al., 2018b). Production of $\mathrm{NH}_{4}{ }^{+}$is the accompanying process associated with oxidation of $\mathrm{SCN}^{-}$to elemental sulfur. Electrons generated from oxidation of $\mathrm{SCN}^{-}$and elemental sulfur drive denitrification which is assumed to mainly take place in two steps: reduction of $\mathrm{NO}_{3}^{-}$to $\mathrm{NO}_{2}^{-}$(denitratation) and further reduction of $\mathrm{NO}_{2}^{-}$to nitrogen gas (denitritation). Therefore, as tabulated in Table $\mathrm{S} 1$ in the supporting information (also contains Tables S2 and S3 and Figure S1), in addition to the inevitable biomass decay, four oxidation-reduction reactions are considered for the $\mathrm{SCN}^{-}$based AD model, all of which lead to biomass growth. As sulfur in $\mathrm{SCN}^{-}$is the real electron donor, $\mathrm{SCN}^{-}$is expressed in terms of $\mathrm{S}$ rather than $\mathrm{N}$ in the model, while biomass is recorded in the form of chemical oxygen demand (COD). Yield coefficient, $\mathrm{Y}_{\mathrm{AD}}$, is used to build the 
relationship between substrate consumption and product/biomass formation. Correct mass balance of all components was ensured through continuity checking according to Hauduc et al. (2010). Double Monod-type kinetic equation is used to describe the enzymatic kinetic processes.

\subsection{Calibration and Validation of Thiocyanate-Based AD Model}

In consideration of the fair number of parameters associated with the $\mathrm{SCN}^{-}$-based $\mathrm{AD}$ model as listed in Table S2, the well-established parameter values should be used as much as possible, which would also reduce the possibility of over-parametrization. Therefore, using the heuristic approach (i.e., process knowledge) as applied by Lu et al. (2018), four sensitive parameters were identified, i.e., $\mu_{\mathrm{SCN}, \mathrm{NO} 3}^{\mathrm{AD}}$ (maximum specific growth rate of $\mathrm{AD}$ bacteria on $\mathrm{SCN}^{-}$and $\mathrm{NO}_{3}{ }^{-}$), $\mu_{\mathrm{SCN}, \mathrm{NO} 2}^{\mathrm{AD}}$ (maximum specific growth rate of $\mathrm{AD}$ bacteria on $\mathrm{SCN}^{-}$and $\mathrm{NO}_{2}{ }^{-}$), $\mu_{\mathrm{S}, \mathrm{NO} 3}^{\mathrm{AD}}$ (maximum specific growth rate of $\mathrm{AD}$ bacteria on $\mathrm{S}$ and $\mathrm{NO}_{3}{ }^{-}$), and $\mu_{\mathrm{S}, \mathrm{NO} 2}^{\mathrm{AD}}$ (maximum specific growth rate of $\mathrm{AD}$ bacteria on $\mathrm{S}$ and $\mathrm{NO}_{2}{ }^{-}$), which should be calibrated using experimental data. The other parameters were directly adopted from literature reported values (see Table S2).

A stepwise protocol was applied to calibrate and validate the developed model, i.e., estimating the values of the four identified sensitive parameters. The first step was to estimate $\mu_{\mathrm{SCN}, \mathrm{NO} 2}^{\mathrm{AD}}$ and $\mu_{\mathrm{S}, \mathrm{NO} 2}^{\mathrm{AD}}$ using Datasets 1-1 to 1-3 with supply of $\mathrm{NO}_{2}^{-}$and $\mathrm{SCN}^{-}$only which involved $\mathrm{SCN}^{-}$-based denitritation (Reaction 2 of Table $\mathrm{S} 1$ ) and S-based denitritation

164 (Reaction 4 of Table S1). On top of the successful completion of the first step, $\mu_{\mathrm{SCN}, \mathrm{NO} 3}^{\mathrm{AD}}$ and

$165 \mu_{\mathrm{S}, \mathrm{NO} 3}^{\mathrm{AD}}$ were estimated in the second step using Datasets 2-1 to 2-4 which further included $\mathrm{SCN}^{-}$-based denitratation (Reaction 1 of Table S1) and S-based denitratation (Reaction 3 of 
Table S1) due to the provision of $\mathrm{NO}_{3}{ }^{-}$and $\mathrm{SCN}^{-}$. It should be noted that the data points for the first two hours of Datasets 2-1 to 2-4 were discarded due to the possible incomplete removal of oxygen that inhibited the reduction of $\mathrm{NO}_{3}{ }^{-}$, as claimed by Pan et al. (2018b).

Being applied to both model calibration and validation, the initial AD bacteria concentration was determined based on the mixed liquid volatile suspended solid (MLVSS) concentration (assumed as $85 \%$ of the measured MLSS concentration, which is commonly used in biological wastewater treatment environments (Randall et al., 1998)) together with the relative abundance of $\mathrm{AD}$ bacteria (see Table 1). A conversion factor of 1.42 (i.e., ratio between COD and VSS) was applied to determine biomass concentration in terms of COD (Contreras et al., 2002). Arrhenius equation was applied to account for the role of varying temperature between datasets. With $30 \square$ as the reference temperature for the developed $\mathrm{SCN}^{-}$-based $\mathrm{AD}$ model, the conversion of the growth rate $(\mu)$ and decay rate $(\mathrm{b})$ in the temperature range between $25 \square$ and $35 \square$ was assumed to follow $\mu(\mathrm{T})=\mu(30) * \theta^{(\mathrm{T}-30)}$ or $\mathrm{b}(\mathrm{T})=\mathrm{b}(30) * \theta^{(\mathrm{T}-30)}$, where $\theta$ was inferred to be 1.1 for AD based on the work of Di Capua et al. (2016).

Parameter estimation was conducted using a modified AQUASIM 2.1d (Reichert, 1998). Uncertainty evaluation was performed according to Batstone et al. (2003) with a 95\% confidence level for significance testing and parameter uncertainty analysis.

\subsection{Verification of Model Integrating Thiocyanate-Based AD with Anammox}

The calibrated/validated $\mathrm{SCN}^{-}$-based $\mathrm{AD}$ model was then integrated with the Anammox model, with the structure and parameters (at the reference temperature of $30 \square$ ) being included in Tables S1 and S2. Dataset 3 with simultaneous contributions of AD and 
Anammox was eventually used to assess the validity of the integrated model without further adjustment in parameter values. In line with the aforementioned model calibration and validation process, the $\mathrm{AD}$ bacteria and Anammox bacteria concentrations were set using same approach, and temperature was also considered using Arrhenius equation (see Table S2).

\subsection{Assessment of Coupling Thiocyanate-Based AD with Anammox in a Biofilm}

\section{Reactor}

The verified integrated model was then applied to simulate the implementation of coupling $\mathrm{SCN}^{-}$-based $\mathrm{AD}$ with Anammox in a biofilm reactor, which is particularly suitable for coculturing slow-growing autotrophs and has been widely applied to study microbial competition/synergy in the long-term operation (Di Capua et al., 2015). As summarized in Table S3, the simulated biofilm reactor had a total volume of $1 \mathrm{~m}^{3}$, consisting of $0.9 \mathrm{~m}^{3}$ of bulk liquid and $0.1 \mathrm{~m}^{3}$ of biofilm. Assuming a uniform steady-state biofilm thickness of 100 $\mu \mathrm{m}$ without consideration of its variation with locations, the total area of biofilm surface was $1000 \mathrm{~m}^{3}$. The inflow rate into the reactor was fixed at $0.083 \mathrm{~m}^{3} / \mathrm{h}$, giving rise to a hydraulic retention time of $12 \mathrm{~h}$.

Scenario 1 was designed to investigate the impact of influent $\mathrm{NH}_{4}{ }^{+}-\mathrm{N} / \mathrm{NO}_{2}{ }^{-} \mathrm{N}$ ratio on the coupling system. Therefore, the influent $\mathrm{SCN}^{-}$and the sum of $\mathrm{NH}_{4}{ }^{+}$and $\mathrm{NO}_{2}{ }^{-}$were controlled at $25 \mathrm{~g}-\mathrm{N} / \mathrm{m}^{3}$ and $150 \mathrm{~g}-\mathrm{N} / \mathrm{m}^{3}$, respectively. The respective concentrations of $\mathrm{NH}_{4}{ }^{+}$and $\mathrm{NO}_{2}{ }^{-}$ were adjusted systematically, rendering an influent $\mathrm{NH}_{4}{ }^{+}-\mathrm{N} / \mathrm{NO}_{2}{ }^{-}-\mathrm{N}$ ratio between $0: 10$ and 9:1. Scenario 2 was further proposed to study the influence of influent $\mathrm{SCN}^{-}$concentration on the $\mathrm{NH}_{4}{ }^{+}-\mathrm{N} / \mathrm{NO}_{2}{ }^{-}-\mathrm{N}$ ratio leading to the optimal treatment performance of the biofilm reactor. To this end, with a varying $\mathrm{NH}_{4}{ }^{+}-\mathrm{N} \mathrm{NO}_{2}{ }^{-}-\mathrm{N}$ ratio at the sum of $\mathrm{NH}_{4}{ }^{+}$and $\mathrm{NO}_{2}{ }^{-}$of $150 \mathrm{~g}-\mathrm{N} / \mathrm{m}^{3}$, the influent $\mathrm{SCN}^{-}$concentration was adjusted between 5 and $40 \mathrm{~g}-\mathrm{N} / \mathrm{m}^{3}$. For both simulation 
scenarios, steady-state nitrogen removal and $\mathrm{SCN}^{-}$removal were both used as criteria to measure the treatment performance of the coupling system. To avoid duplicate representation, nitrogen content in $\mathrm{SCN}^{-}$was not accounted for when calculating the removal efficiency of $\mathrm{TN}$, which was termed as sum of $\mathrm{NO}_{3}{ }^{-}-\mathrm{N}, \mathrm{NO}_{2}{ }^{-}-\mathrm{N}$, and $\mathrm{NH}_{4}{ }^{+}-\mathrm{N}$ hereafter.

Both simulation scenarios assumed an initial biofilm thickness of $1 \mu \mathrm{m}$ and were run long enough to reach the steady state which was controlled by the surface detachment velocity equation reported by Lackner et al. (2008). The resistance approach based on Fick's first law was used to describe the transport of dissolved components into or out of the biofilm. Detailed information about the reactor setup and biofilm characteristics is provided in Table S3.

\section{RESULTS}

\subsection{Calibration and Validation of Thiocyanate-Based AD Model}

Figures $2 \mathrm{~A}$ and $2 \mathrm{~B}$ illustrate the first-step calibration results of the denitritation processes of the developed $\mathrm{SCN}^{-}$-based $\mathrm{AD}$ model using Datasets 1-1 and 1-2. At the initial $\mathrm{NO}_{2}^{-}-\mathrm{N} / \mathrm{SCN}^{-}-$ $\mathrm{N}$ ratio of 3.0, although $\mathrm{SCN}^{-}$was completely removed, $\mathrm{NO}_{2}^{-}$still remained at the end of the batch tests. With the simultaneous consumption of $\mathrm{SCN}^{-}$and $\mathrm{NO}_{2}{ }^{-}, \mathrm{SO}_{4}{ }^{2-}$ and $\mathrm{NH}_{4}{ }^{+}$were formed. The great agreement between model predictions and experimental measurements in Figures $2 \mathrm{~A}\left(\mathrm{R}^{2}=0.98\right)$ and $2 \mathrm{~B}\left(\mathrm{R}^{2}=0.99\right)$ supported the goodness of the calibration for the denitritation processes. The validation of the denitritation processes was performed using Dataset 1-3, with results presented in Figure 2C. The good match between the model predicted and measured trends $\left(\mathrm{R}^{2}=0.99\right)$ verified the validity of $\mu_{\mathrm{SCN}, \mathrm{NO} 2}^{\mathrm{AD}}$ and $\mu_{\mathrm{S}, \mathrm{NO} 2}^{\mathrm{AD}}$ for the developed $\mathrm{SCN}^{-}$-based $\mathrm{AD}$ model, which were estimated at $0.0045 \pm 0.0001 \mathrm{~g} /(\mathrm{g} \cdot \mathrm{h})$ and $0.157 \pm 0.021 \mathrm{~g} /(\mathrm{g} \cdot \mathrm{h})$, respectively. 
243 The second-step calibration results of the denitratation processes of the developed $\mathrm{SCN}^{-}$based AD model using Datasets 2-1 and 2-2 are exhibited in Figures 3A and 3B. As explained by Pan et al. (2018b), the data points for the first two hours (the shadow regions) were excluded in this work due to the possible interference of oxygen remaining in the beginning of the batch tests. At the relatively low initial $\mathrm{NO}_{3}{ }^{-}-\mathrm{N} / \mathrm{SCN}^{-}-\mathrm{N}$ ratios of 1.0 (Dataset 2-1) and 1.5 (Dataset 2-2), both $\mathrm{NO}_{3}{ }^{-}$and $\mathrm{SCN}^{-}$were nearly completely removed at the end of the batch tests. In addition to $\mathrm{SO}_{4}{ }^{2-}$ and $\mathrm{NH}_{4}{ }^{+}, \mathrm{NO}_{2}{ }^{-}$was also formed. Nevertheless, after $\mathrm{NO}_{3}{ }^{-}$was completely removed in Dataset 2-1 (Figure 3A), $\mathrm{NO}_{2}^{-}$started to be consumed, confirming the contribution of the denitritation processes. The fine match between model predicted and experimentally measured profiles in Figures $3 A\left(R^{2}=0.88\right)$ and $3 B\left(R^{2}=0.92\right)$ proved the goodness of calibrating the denitratation processes. Figures $3 \mathrm{C}$ and $3 \mathrm{D}$ show the validation results of the denitratation processes using Datasets 2-3 and 2-4. Because of the elevated $\mathrm{NO}_{3}{ }^{-}-\mathrm{N} / \mathrm{SCN}^{-}-\mathrm{N}$ ratios (i.e., 2.0 and 3.0), $\mathrm{SCN}^{-}$was completely consumed while some $\mathrm{NO}_{3}{ }^{-}$remained at the end of the batch tests. The satisfying agreement between model predictions and experimental measurements in Figures $3 C\left(R^{2}=0.96\right)$ and $3 D\left(R^{2}=0.92\right)$ supported the validity of calibrated values of $\mu_{\mathrm{SCN}, \mathrm{NO} 3}^{\mathrm{AD}}(0.0048 \pm 0.0003 \mathrm{~g} /(\mathrm{g} \cdot \mathrm{h}))$ and $\mu_{\mathrm{S}, \mathrm{NO} 3}^{\mathrm{AD}}$ $(0.0064 \pm 0.0002 \mathrm{~g} /(\mathrm{g} \cdot \mathrm{h}))$ for the denitratation processes of the developed $\mathrm{SCN}^{-}$-based AD model.

The $95 \%$ confidence regions for $\mu_{\mathrm{SCN}, \mathrm{NO} 2}^{\mathrm{AD}}$ and $\mu_{\mathrm{S}, \mathrm{NO} 2}^{\mathrm{AD}}$ and for $\mu_{\mathrm{SCN}, \mathrm{NO} 3}^{\mathrm{AD}}$ and $\mu_{\mathrm{S}, \mathrm{NO} 3}^{\mathrm{AD}}$ in combination with their uncorrelated confidence intervals obtained are delineated in Figures S1A and S1B, respectively. The good reliability and identifiability of the four estimated parameter values were supported by the small uncorrelated confidence intervals of parameters lying inside the correlated confidence region. 


\subsection{Verification of Model Integrating Thiocyanate-Based AD with Anammox}

269

270

271

272

273

274

275

276

277

278

279

280

281

282

283

284

285

286

287

288

289

290

291

Figure 4 illustrates the verification results of the calibrated/validated $\mathrm{SCN}^{-}$-based $\mathrm{AD}$ model integrated with the Anammox model using Dataset 3. With the consumption of $\mathrm{NO}_{2}{ }^{-}$and $\mathrm{SCN}^{-}$, neither $\mathrm{NO}_{3}{ }^{-}$nor $\mathrm{NH}_{4}{ }^{+}$was observed in significant amount throughout the batch test, proving the simultaneous contributions of $\mathrm{AD}$ and Anammox. The fact that the integrated model could capture the experimentally measured profiles to a high level $\left(R^{2}=0.94\right)$ manifested the validity and capability of the integrated model to describe the joint presence of $\mathrm{AD}$ and Anammox metabolisms. The evaluated integrated model could therefore be reliably applied in the following section to assess the feasibility of coupling $\mathrm{SCN}^{-}$-based $\mathrm{AD}$ with Anammox in a biofilm reactor.

\subsection{Effect of $\mathrm{NH}_{4}{ }^{+}-\mathrm{N} / \mathrm{NO}_{2}{ }^{-}-\mathrm{N}$ Ratio on Coupling Thiocyanate-Based AD with Anammox}

The long-term impact of influent $\mathrm{NH}_{4}{ }^{+}-\mathrm{N}^{-} \mathrm{NO}_{2}{ }^{-}-\mathrm{N}$ ratio on the microbial composition of the biofilm as well as $\mathrm{TN}$ and $\mathrm{SCN}^{-}$removal efficiencies (Scenario 1) is delineated in Figure 5. At the $\mathrm{SCN}^{-}$supply of $25 \mathrm{~g}-\mathrm{N} / \mathrm{m}^{3}$ in Scenario 1 , the maximum $\mathrm{NO}_{2}^{-}$consumption and $\mathrm{NH}_{4}^{+}$ production via $\mathrm{SCN}^{-}$-based $\mathrm{AD}$ were fixed. An influent $\mathrm{NH}_{4}{ }^{+}-\mathrm{N} / \mathrm{NO}_{2}{ }^{-}-\mathrm{N}$ ratio of 0:10 (i.e., no external supply of $\mathrm{NH}_{4}^{+}$) meant a complete utilization of $\mathrm{SCN}^{-}$-based $\mathrm{AD}$ but an oversupply of $\mathrm{NO}_{2}^{-}$as the electron acceptor for Anammox bacteria. Consequently, $\mathrm{AD}$ bacteria dominated the biofilm at a relative abundance of $76 \%$ with the coexistence of Anammox bacteria (24\%). Nearly complete removal of $\mathrm{SCN}^{-}(98.3 \%)$ was achieved, while the $\mathrm{TN}$ removal efficiency was only $52.8 \%$. With the influent $\mathrm{NH}_{4}{ }^{+}-\mathrm{N} / \mathrm{NO}_{2}{ }^{-} \mathrm{N}$ ratio increasing to 2:8, the contribution of Anammox was enhanced through the elevated external $\mathrm{NH}_{4}{ }^{+}$supply. Therefore, the relative abundance of Anammox bacteria increased while that of AD bacteria decreased, leading to the increasing $\mathrm{TN}$ removal without hindering the $\mathrm{SCN}^{-}$removal. At the 
influent $\mathrm{NH}_{4}{ }^{+}-\mathrm{N} / \mathrm{NO}_{2}{ }^{-}-\mathrm{N}$ ratio of around 3:7, a balanced synergy between $\mathrm{AD}$ bacteria $(57 \%)$ and Anammox bacteria (43\%) was obtained, generating a TN removal efficiency of $99.0 \%$ and a concomitant $\mathrm{SCN}^{-}$removal efficiency of $95.0 \%$. Further increase in the influent $\mathrm{NH}_{4}{ }^{+}-$ $\mathrm{N} / \mathrm{NO}_{2}{ }^{-}-\mathrm{N}$ ratio until 9:1 intensified the competition between $\mathrm{AD}$ bacteria and Anammox bacteria for $\mathrm{NO}_{2}{ }^{-}$availability so that Anammox bacteria gained advantage over AD bacteria. Consequently, the relative abundance of $\mathrm{AD}$ bacteria decreased to $5 \%$ while that of Anammox bacteria increased to $95 \%$ at the influent $\mathrm{NH}_{4}{ }^{+}-\mathrm{N} / \mathrm{NO}_{2}{ }^{-}-\mathrm{N}$ ratio of $9: 1$. As only $\mathrm{NO}_{2}^{-}$was completely used, both the $\mathrm{TN}$ and $\mathrm{SCN}^{-}$removal decreased with the increasing influent $\mathrm{NH}_{4}{ }^{+}-\mathrm{N} / \mathrm{NO}_{2}{ }^{-}-\mathrm{N}$ ratio.

\subsection{Effect of $\mathrm{SCN}^{-}$on Optimal $\mathrm{NH}_{4}{ }^{+}-\mathrm{N} / \mathrm{NO}_{2}{ }^{-}-\mathrm{N}$ Ratio for Coupling Thiocyanate-Based}

\section{AD with Anammox}

Figure 6 illustrates the long-term impact of influent $\mathrm{SCN}^{-}$concentration on the optimal $\mathrm{NH}_{4}{ }^{+}-$ $\mathrm{N} / \mathrm{NO}_{2}{ }^{-} \mathrm{-N}$ ratio leading to highest $\mathrm{TN}$ removal as well as corresponding microbial composition of the biofilm and accompanying $\mathrm{SCN}^{-}$removal efficiency (Scenario 2). Simultaneous high-level removal of $\mathrm{TN}(99.0 \pm 0.3 \%)$ and $\mathrm{SCN}^{-}(95.6 \pm 1.2 \%)$ could be obtained at the influent $\mathrm{SCN}^{-}$concentration between 5 and $40 \mathrm{~g}-\mathrm{N} / \mathrm{m}^{3}$. However, the corresponding optimal $\mathrm{NH}_{4}{ }^{+}-\mathrm{N} / \mathrm{NO}_{2}{ }^{-}-\mathrm{N}$ ratio decreased with the increasing influent $\mathrm{SCN}^{-}$ concentration. This was because of the increasing need of $\mathrm{AD}$ bacteria for $\mathrm{NO}_{2}^{-}$as the electron acceptor at the increasing influent $\mathrm{SCN}^{-}$concentration. Therefore, in terms of the microbial community, the relative abundance of $\mathrm{AD}$ bacteria increased while that of Anammox bacteria decreased.

\section{DISCUSSION}


316 Different from the model describing aerobic autotrophic biodegradation of $\mathrm{SCN}^{-}$that has

317 been studied previously (Du Plessis et al., 2001; Hung and Pavlostathis, 1999), the SCN ${ }^{-}$

318 based AD model studied in this work creates the opportunity to assess the treatment of $\mathrm{SCN}^{-}$

319 containing wastewater using anoxic technologies, which are generally regarded as more cost-

320 effective. Through a well-designed two-step calibration and validation process, the $\mathrm{SCN}^{-}$-

321 based AD model was first reliably obtained in this work, as proved in Figures 2 and 3.

322 Compared to the work of Pan et al. (2019) where the sequential reduction of $\mathrm{NO}_{3}{ }^{-}$to nitrogen gas via $\mathrm{NO}_{2}^{-}$and elemental sulfur as the intermediate were not considered, the $\mathrm{SCN}^{-}$-based AD model developed in this work could better represent the true metabolic pathways, thus enabling more accurate model-based evaluations.

The developed $\mathrm{SCN}^{-}$-based $\mathrm{AD}$ model was integrated with the Anammox model, which, after being verified with literature reported experimental data (see Figure 4), was then used to assess the microbial competition/synergy between AD bacteria and Anammox bacteria in a coupling biofilm reactor under different operating conditions. It should be pointed out that the potential inhibition of $\mathrm{SCN}^{-}$on Anammox bacteria was not considered in the model of this work, which certainly could be modified upon the future availability of relevant information. The good match between the model predicted and measured trends presented in Figures 2 to 4 proved the applicability of the model parameters obtained in this work under the concentration conditions of $\mathrm{SCN}^{-}, \mathrm{NH}_{4}{ }^{+}$, and $\mathrm{NO}_{2}{ }^{-}$studied and the temperature conditions between $25 \square$ and $35 \square$. As shown in Figure 5, the influent $\mathrm{NH}_{4}{ }^{+}-\mathrm{N} / \mathrm{NO}_{2}{ }^{-} \mathrm{N}$ ratio in the presence of a certain $\mathrm{SCN}^{-}$concentration should be controlled at a proper level so that the maximum synergy between AD bacteria and Anammox bacteria was achieved while their competition for $\mathrm{NO}_{2}^{-}$was minimized. Only under this operating condition would the maximum removal of nitrogen and $\mathrm{SCN}^{-}$be achieved simultaneously. However, when the 
influent $\mathrm{SCN}^{-}$level changed, the corresponding $\mathrm{NH}_{4}{ }^{+}-\mathrm{N} / \mathrm{NO}_{2}{ }^{-} \mathrm{N}$ ratio for simultaneous maximum removal (>95\%) of $\mathrm{TN}$ and $\mathrm{SCN}^{-}$should change as well. In general, there existed a negative relationship between the influent $\mathrm{SCN}^{-}$concentration and the optimal $\mathrm{NH}_{4}{ }^{+}-\mathrm{N}^{-} \mathrm{NO}_{2}{ }^{-}-$ $\mathrm{N}$ ratio needed (Figure 6). Therefore, in real application, the extent of partial nitritation of wastewater containing $\mathrm{SCN}^{-}$and $\mathrm{NH}_{4}^{+}$should be properly regulated so that a good $\mathrm{NH}_{4}{ }^{+}-$ $\mathrm{N} / \mathrm{NO}_{2}-\mathrm{N}$ ratio in the presence of $\mathrm{SCN}^{-}$is provided for the coupling system. Moreover, compared with single Anammox process, the integration of $\mathrm{SCN}^{-}$-based $\mathrm{AD}$ with Anammox enhances nitrogen removal through utilizing $\mathrm{NO}_{3}{ }^{-}$produced by Anammox and adds on $\mathrm{SCN}^{-}$ removal, although it requires a lower $\mathrm{NH}_{4}{ }^{+}-\mathrm{N} / \mathrm{NO}_{2}{ }^{-} \mathrm{N}$ ratio and hence a higher extent of the preceding partial nitritation. In brief, the integrated process still stands a promising alternative for treating industrial wastewaters containing substantial amount of $\mathrm{SCN}^{-}$and $\mathrm{NH}_{4}{ }^{+}$.

The applicability of the integrated model developed in this work could be further extended to predicting the fate of other background pollutants such as COD or biochemical oxygen demand, if present, through integration with well-established process models such as activated sludge models. Future work could also focus on the extension of the integrated model with relevant process kinetics to describe the role of $\mathrm{pH}$ and the formation of complex from the reactions between $\mathrm{SCN}^{-}$and metal ions, as the availability of $\mathrm{SCN}^{-}, \mathrm{NH}_{4}{ }^{+}$, or/and $\mathrm{NO}_{2}^{-}$which directly affects the treatment performance is heavily dependent on both $\mathrm{pH}$ dynamics and the potential presence of metal ions in wastewater.

\section{CONCLUSIONS}

363 Using literature reported experimental data, a complete $\mathrm{SCN}^{-}$-based $\mathrm{AD}$ model taking into account not only relevant processes but also associated key intermediates was firstly developed/calibrated/validated and then integrated/verified with the well-established 
366 Anammox model. The assessment results by using the integrated model showed that the

$367 \mathrm{NH}_{4}{ }^{+}-\mathrm{N} / \mathrm{NO}_{2}{ }^{-}-\mathrm{N}$ ratio in the presence of a certain $\mathrm{SCN}^{-}$level should be controlled at a proper

368 value so that the maximum synergy between AD bacteria and Anammox bacteria was

369 achieved whilst their competition for $\mathrm{NO}_{2}^{-}$was minimized. For the simultaneous maximum

370 removal $(>95 \%)$ of nitrogen and $\mathrm{SCN}^{-}$, there existed a negative relationship between the

371 influent $\mathrm{SCN}^{-}$concentration and the optimal $\mathrm{NH}_{4}{ }^{+}-\mathrm{N} / \mathrm{NO}_{2}{ }^{-}-\mathrm{N}$ ratio needed. The findings

372 obtained would benefit the potential practical design and application of coupling $\mathrm{SCN}^{-}$-based

$373 \mathrm{AD}$ with Anammox in the treatment of wastewater that contains $\mathrm{SCN}^{-}$and $\mathrm{NH}_{4}^{+}$.

ACKNOWLEDGEMENT

This work was partially supported by the National Natural Science Foundation of China (No.

51578391 and 51538008) and the State Key Laboratory of Pollution Control and Resource

Reuse Foundation (No. PCRRK18007). The authors are grateful to the research collaboration.

DECLARATIONS OF INTEREST

None.

\section{REFERENCES}

Batstone, D.J., Pind, P.F., Angelidaki, I., 2003. Kinetics of thermophilic, anaerobic oxidation of straight and branched chain butyrate and valerate. Biotechnology and Bioengineering 84, 195-204.

Bhunia, F., Saha, N.C., Kaviraj, A., 2000. Toxicity of Thiocyanate to Fish, Plankton, Worm, and Aquatic Ecosystem. Bulletin of Environmental Contamination and Toxicology 64, 197-204. 
Broman, E., Jawad, A., Wu, X., Christel, S., Ni, G., Lopez-Fernandez, M., Sundkvist, J.-E., Dopson, M., 2017. Low temperature, autotrophic microbial denitrification using thiosulfate or thiocyanate as electron donor. Biodegradation 28, 287-301.

Contreras, E.M., Bertola, N.C., Giannuzzi, L., Zaritzky, N.E., 2002. A modified method to determine biomass concentration as COD in pure cultures and in activated sludge systems. Water Sa 28, 463-468.

Di Capua, F., Ahoranta, S.H., Papirio, S., Lens, P.N.L., Esposito, G., 2016. Impacts of sulfur source and temperature on sulfur-driven denitrification by pure and mixed cultures of Thiobacillus. Process Biochemistry 51, 1576-1584.

Di Capua, F., Papirio, S., Lens, P.N.L., Esposito, G., 2015. Chemolithotrophic denitrification in biofilm reactors. Chemical Engineering Journal 280, 643-657.

Du Plessis, C.A., Barnard, P., Muhlbauer, R.M., Naldrett, K., 2001. Empirical model for the autotrophic biodegradation of thiocyanate in an activated sludge reactor. Letters in Applied Microbiology 32, 103-107.

Erdoğan, M.F., 2003. Thiocyanate overload and thyroid disease. BioFactors 19, 107-111.

Felföldi, T., Székely, A.J., Gorál, R., Barkács, K., Scheirich, G., András, J., Rácz, A., Márialigeti, K., 2010. Polyphasic bacterial community analysis of an aerobic activated sludge removing phenols and thiocyanate from coke plant effluent. Bioresource Technology 101, 3406-3414.

Gould, W.D., King, M., Mohapatra, B.R., Cameron, R.A., Kapoor, A., Koren, D.W., 2012. A critical review on destruction of thiocyanate in mining effluents. Minerals Engineering $34,38-47$.

Hauduc, H., Rieger, L., Takács, I., Héduit, A., Vanrolleghem, P., Gillot, S., 2010. A systematic approach for model verification: application on seven published activated sludge models. Water Science and Technology 61, 825-839. 
Hung, C.-H., Pavlostathis, S.G., 1999. Kinetics and modeling of autotrophic thiocyanate biodegradation. Biotechnology and Bioengineering 62, 1-11.

Kim, Y.M., Cho, H.U., Lee, D.S., Park, C., Park, D., Park, J.M., 2011. Response of nitrifying bacterial communities to the increased thiocyanate concentration in pre-denitrification process. Bioresource Technology 102, 913-922.

Kim, Y.M., Park, D., Jeon, C.O., Lee, D.S., Park, J.M., 2008. Effect of HRT on the biological pre-denitrification process for the simultaneous removal of toxic pollutants from cokes wastewater. Bioresource Technology 99, 8824-8832.

Lackner, S., Terada, A., Smets, B.F., 2008. Heterotrophic activity compromises autotrophic nitrogen removal in membrane-aerated biofilms: Results of a modeling study. Water Research 42, 1102-1112.

Lu, X., D. S. Pereira, T., Al-Hazmi, H.E., Majtacz, J., Zhou, Q., Xie, L., Makinia, J., 2018. Model-Based Evaluation of N2O Production Pathways in the Anammox-Enriched Granular Sludge Cultivated in a Sequencing Batch Reactor. Environmental Science \& Technology 52, 2800-2809.

Pan, J., Ma, J., Wu, H., Chen, B., He, M., Liao, C., Wei, C., 2019. Application of metabolic division of labor in simultaneous removal of nitrogen and thiocyanate from wastewater. Water Research 150, 216-224.

Pan, J., Ma, J., Wu, H., Ren, Y., Fu, B., He, M., Zhu, S., Wei, C., 2018a. Simultaneous removal of thiocyanate and nitrogen from wastewater by autotrophic denitritation process. Bioresource Technology 267, 30-37.

Pan, J., Wei, C., Fu, B., Ma, J., Preis, S., Wu, H., Zhu, S., 2018b. Simultaneous nitrite and ammonium production in an autotrophic partial denitrification and ammonification of wastewaters containing thiocyanate. Bioresource Technology 252, 20-27. 
439 Randall, C.W., Barnard, J.L., Stensel, H.D., 1998. Design and retrofit of wastewater 440 treatment plants for biological nutritient removal. CRC Press.

441 Reichert, P., 1998. AQUASIM 2.0-Computer program for the identification and simulation of aquatic systems, EAWAG, Dubendorf, Switzerland.

443 Sorokin, D.Y., Tourova, T.P., Lysenko, A.M., Kuenen, J.G., 2001. Microbial Thiocyanate $444 \quad$ Utilization under Highly Alkaline Conditions. Applied and Environmental Microbiology $67,528$.

Staib, C., Lant, P., 2007. Thiocyanate degradation during activated sludge treatment of cokeovens wastewater. Biochemical Engineering Journal 34, 122-130.

Xu, G., Peng, J., Feng, C., Fang, F., Chen, S., Xu, Y., Wang, X., 2015. Evaluation of simultaneous autotrophic and heterotrophic denitrification processes and bacterial community structure analysis. Applied Microbiology and Biotechnology 99, 6527-6536.

Xu, G., Yin, F., Chen, S., Xu, Y., Yu, H.-Q., 2016. Mathematical modeling of autotrophic denitrification (AD) process with sulphide as electron donor. Water Research 91, 225234.

454 Yang, W., Zhao, Q., Lu, H., Ding, Z., Meng, L., Chen, G.-H., 2016. Sulfide-driven 455 autotrophic denitrification significantly reduces N2O emissions. Water Research 90, 176-184. 


\section{ACCEPTED MANUSCRIPT}

Table and Figure Legends

460

461 Table 1. Experimental data for model calibration, validation, and evaluation

462

463

Figure 1. Pathways of $\mathrm{SCN}^{-}$-based autotrophic denitrification (AD) and Anammox and their 464 interactions.

465

466

Figure 2. (A and $\mathbf{B})$ Calibration and $(\mathbf{C})$ validation results of denitritation processes of the $\mathrm{SCN}^{-}$-based autotrophic denitrification (AD) model.

468

469

Figure 3. (A and $\mathbf{B})$ Calibration and $(\mathbf{C}$ and $\mathbf{D})$ validation results of denitratation processes of 470 the $\mathrm{SCN}^{-}$-based autotrophic denitrification (AD) model.

471

472

Figure 4. Verification results of the model integrating $\mathrm{SCN}^{-}$-based autotrophic denitrification 473 (AD) with Anammox.

474

475

Figure 5. Long-term impact of $\mathrm{NH}_{4}{ }^{+}-\mathrm{N} / \mathrm{NO}_{2}{ }^{-}-\mathrm{N}$ ratio on microbial composition of the biofilm as well as $\mathrm{TN}$ and $\mathrm{SCN}^{-}$removal efficiencies (Scenario 1).

477

478 Figure 6. Long-term impact of $\mathrm{SCN}^{-}$level on optimal $\mathrm{NH}_{4}{ }^{+}-\mathrm{N}^{-} \mathrm{NO}_{2}{ }^{-} \mathrm{N}$ ratio leading to 479 highest TN removal as well as corresponding microbial composition of the biofilm and 480 accompanying $\mathrm{SCN}^{-}$removal efficiency (Scenario 2). 
Table 1. Experimental data for model calibration, validation, and evaluation

\begin{tabular}{|c|c|c|c|c|c|c|c|c|c|}
\hline Dataset & $\begin{array}{c}\text { Initial } \\
\text { SCN }^{-} \\
\left(\mathrm{g}-\mathrm{N} / \mathrm{m}^{3}\right) \\
\end{array}$ & $\begin{array}{c}\text { Initial } \\
\mathbf{N O}_{2}^{-} \\
\left(\mathrm{g}-\mathrm{N} / \mathrm{m}^{3}\right) \\
\end{array}$ & $\begin{array}{c}\text { Initial } \\
\mathrm{NO}_{3}^{-} \\
\left(\mathrm{g}-\mathrm{N} / \mathrm{m}^{3}\right) \\
\end{array}$ & $\begin{array}{c}\text { MLSS-AD } \\
\qquad\left(\mathrm{g} / \mathrm{m}^{3}\right)\end{array}$ & $\begin{array}{c}\text { Abundance of } \\
\text { AD }\end{array}$ & $\begin{array}{c}\text { MLSS-AN } \\
\left(\mathrm{g} / \mathrm{m}^{3}\right)\end{array}$ & Abundance of AN & $\begin{array}{c}\text { Temperature } \\
(\square)\end{array}$ & Source \\
\hline $1-1$ & 25 & 75 & \multirow{3}{*}{0} & \multirow{3}{*}{1000} & \multirow{3}{*}{$38 \%$} & \multirow{3}{*}{0} & & \multirow{3}{*}{25} & \multirow{3}{*}{ Pan et al. (2018a) } \\
\hline $1-2$ & 50 & 150 & & & & & & & \\
\hline $1-3$ & 75 & 225 & & & & & & & \\
\hline $2-1$ & 50 & \multirow{4}{*}{0} & 50 & \multirow{4}{*}{500} & \multirow{4}{*}{$64.8 \%$} & & \multirow{4}{*}{0} & \multirow{4}{*}{35} & \multirow{4}{*}{ Pan et al. (2018b) } \\
\hline $2-2$ & 40 & & 60 & & & & & & \\
\hline $2-3$ & 33.3 & & 66.7 & & & & & & \\
\hline $2-4$ & 25 & & 75 & & & & & & \\
\hline 3 & 25 & 75 & 0 & 350 & $38 \%$ & 1400 & $14.4 \%$ & 30 & Pan et al. (2019) \\
\hline
\end{tabular}




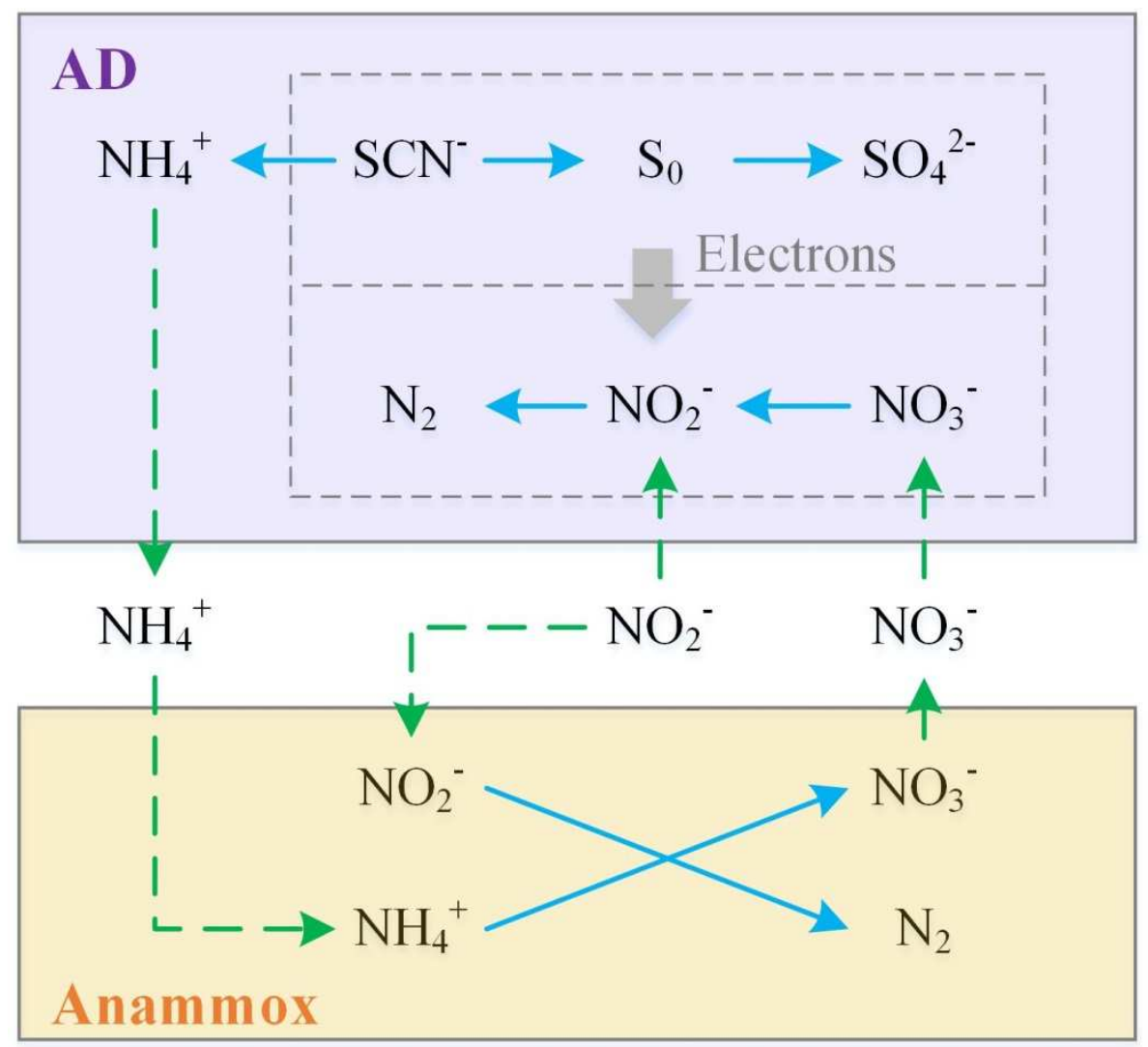

Figure 1. Pathways of $\mathrm{SCN}^{-}$-based autotrophic denitrification (AD) and Anammox and their interactions. 

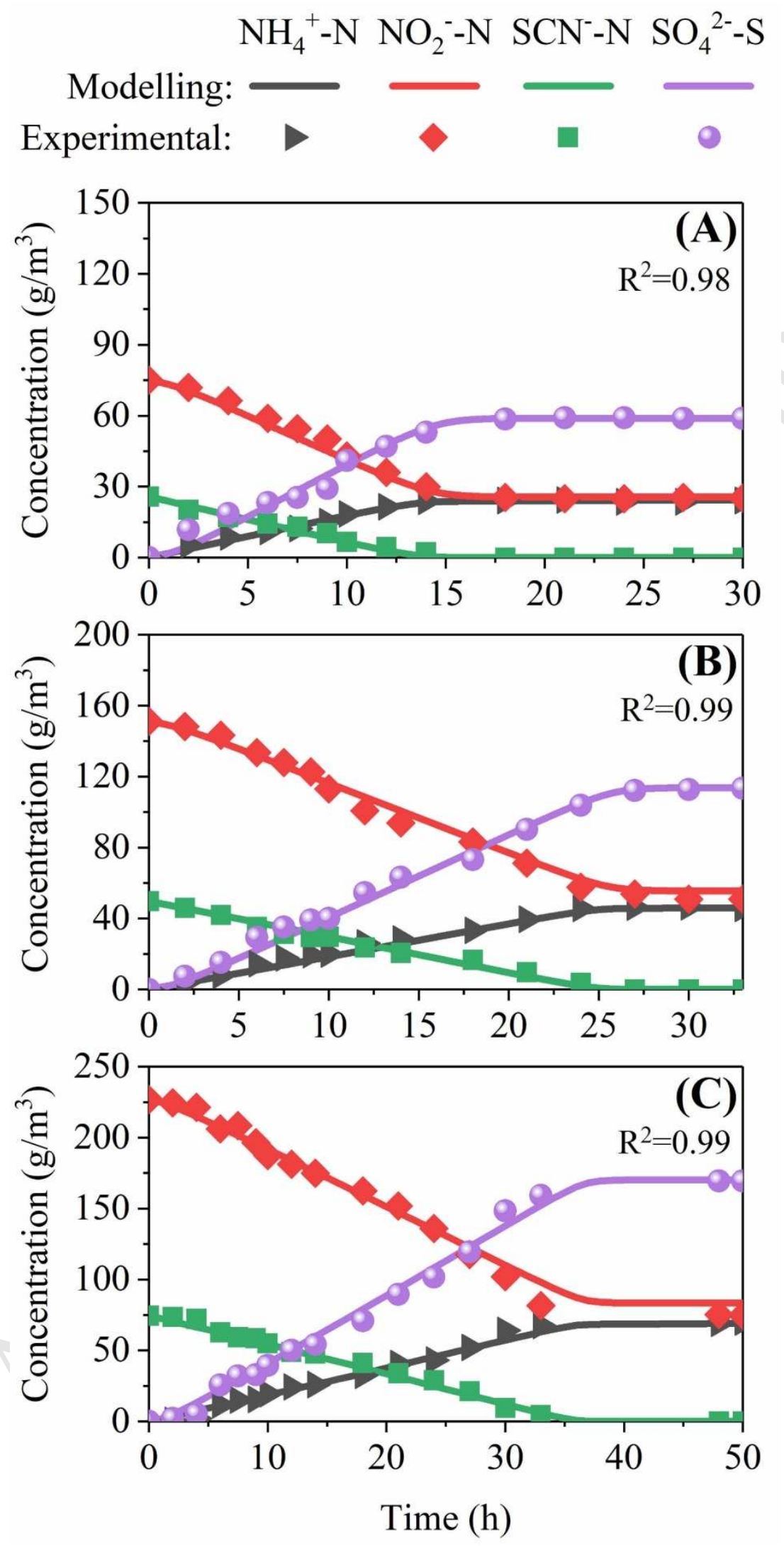

Figure 2. (A and $\mathbf{B})$ Calibration and $(\mathbf{C})$ validation results of denitritation processes of the $\mathrm{SCN}^{-}$-based autotrophic denitrification (AD) model. 

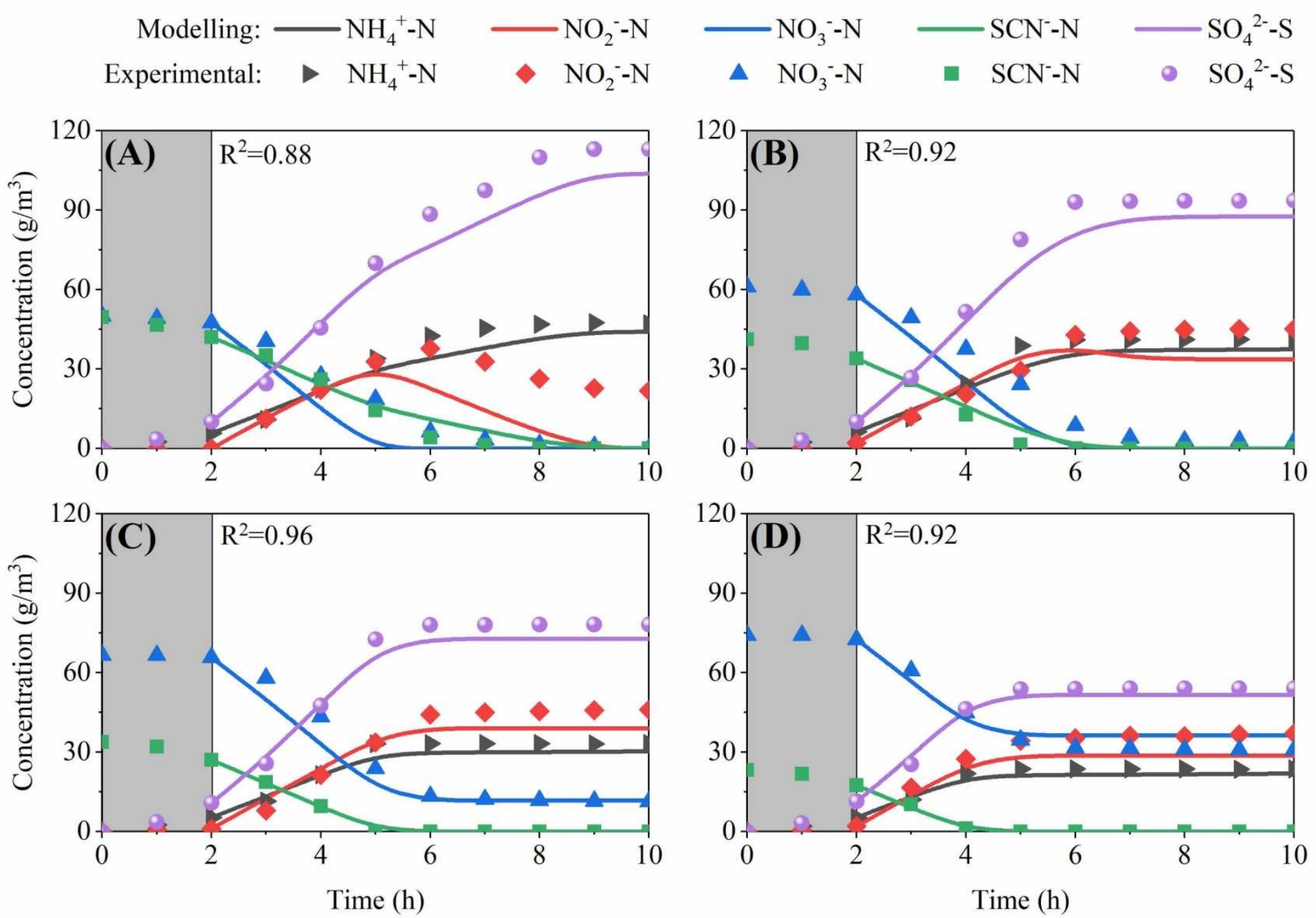

Figure 3. (A and $\mathbf{B})$ Calibration and $(\mathbf{C}$ and $\mathbf{D})$ validation results of denitratation processes of the $\mathrm{SCN}^{-}$-based autotrophic denitrification (AD) model. 


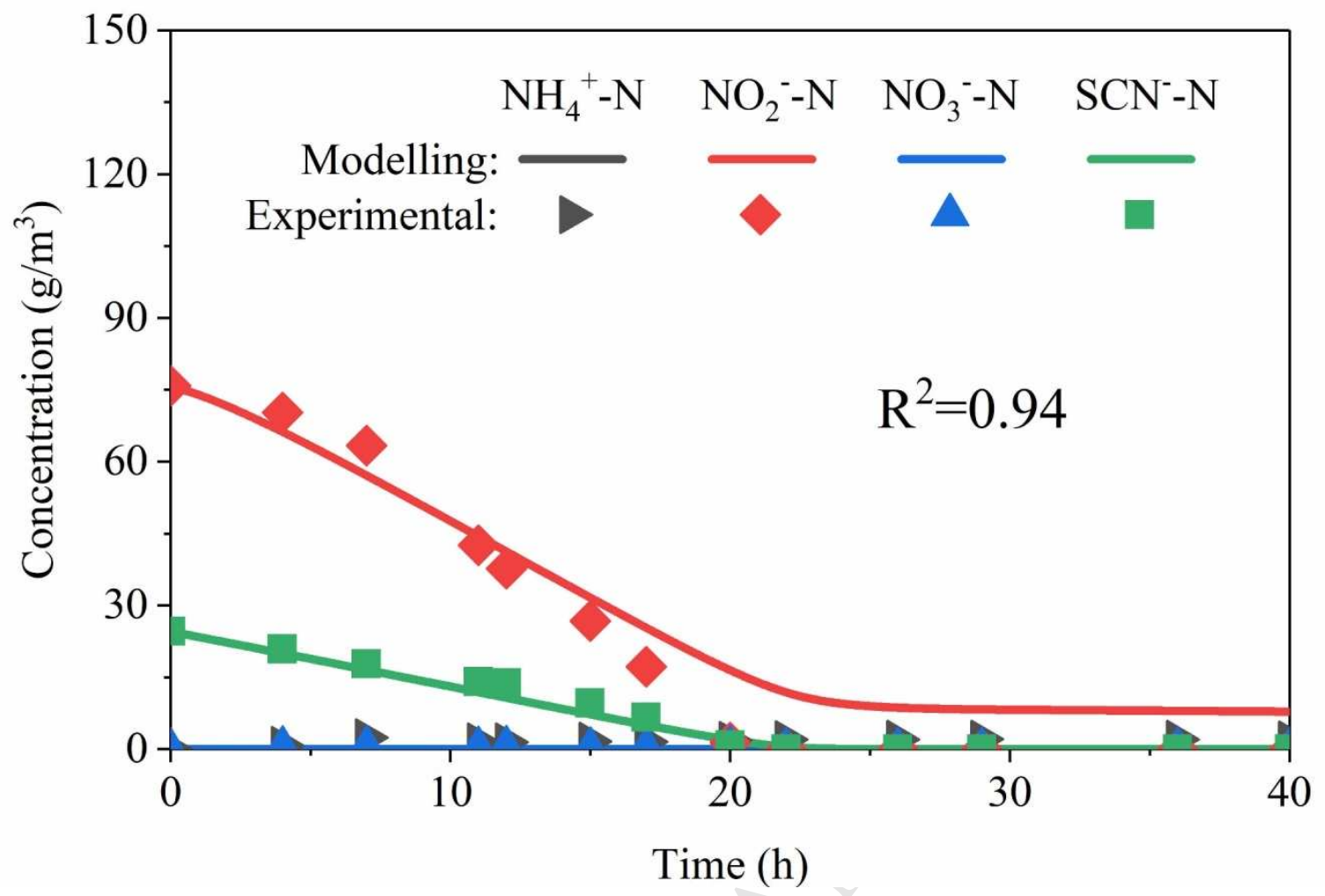

Figure 4. Verification results of the model integrating $\mathrm{SCN}^{-}$-based autotrophic denitrification (AD) with Anammox. 


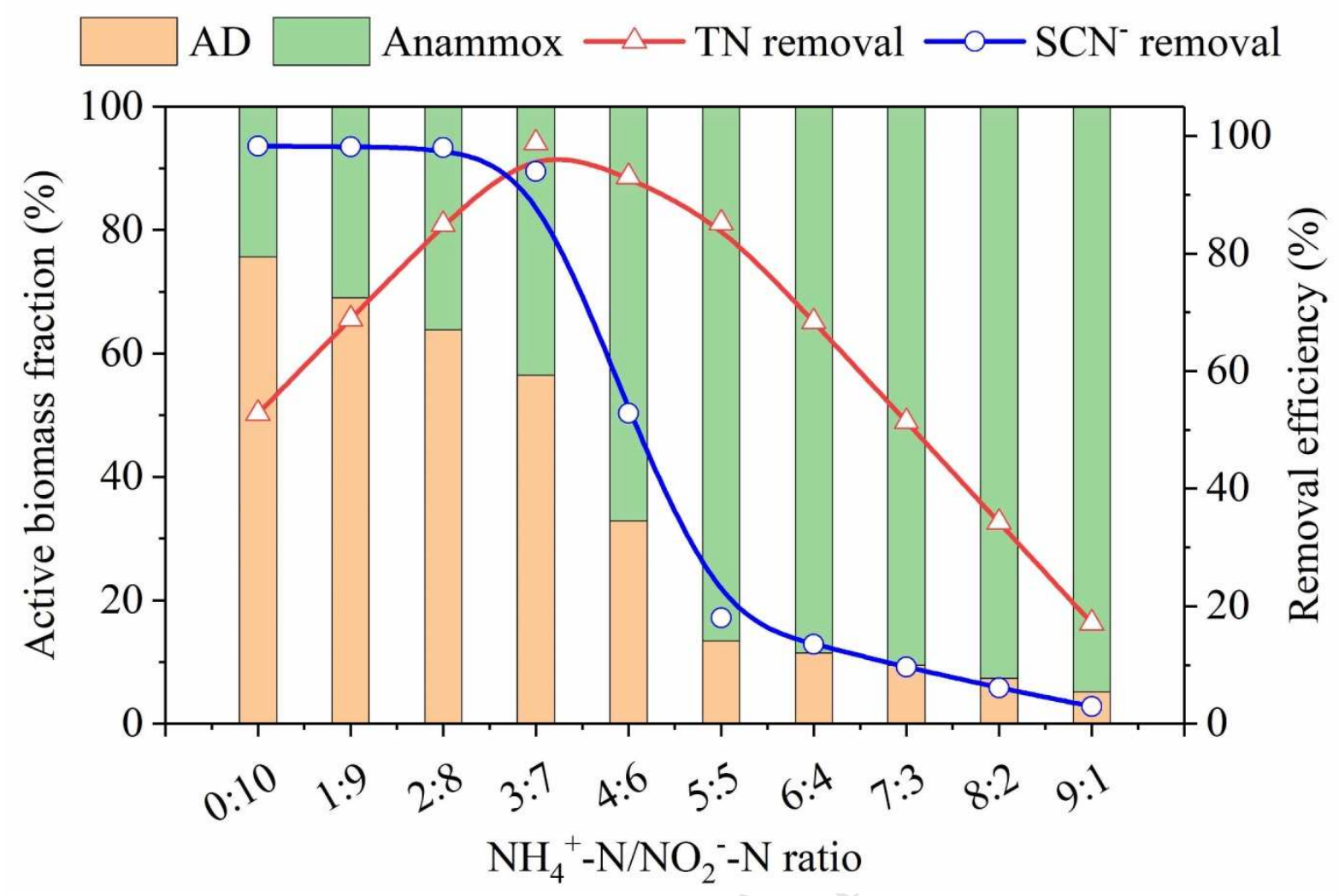

Figure 5. Long-term impact of $\mathrm{NH}_{4}{ }^{+}-\mathrm{N} / \mathrm{NO}_{2}{ }^{-} \mathrm{N}$ ratio on microbial composition of the biofilm as well as $\mathrm{TN}$ and $\mathrm{SCN}^{-}$removal efficiencies (Scenario 1). 


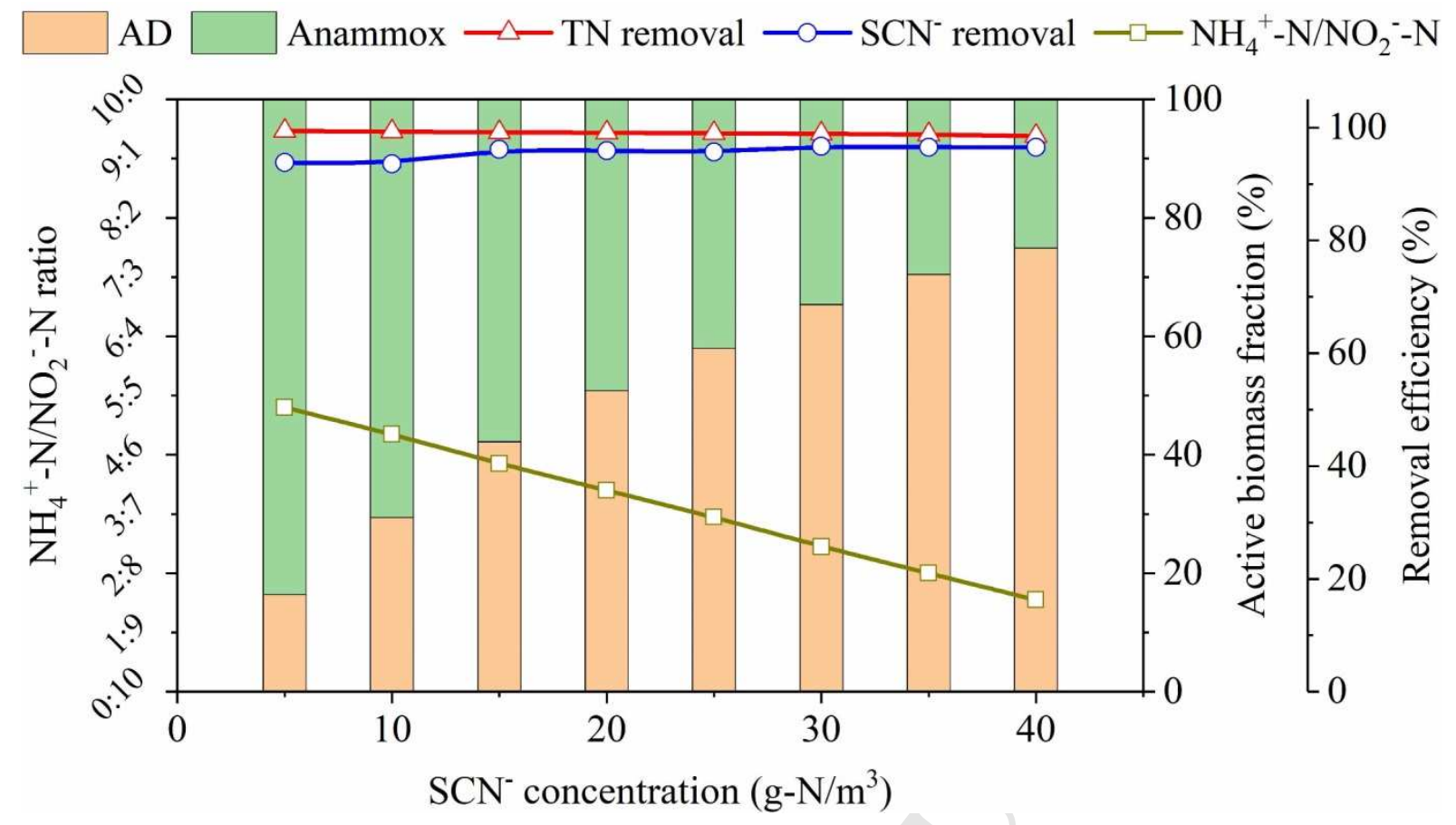

Figure 6. Long-term impact of $\mathrm{SCN}^{-}$level on optimal $\mathrm{NH}_{4}{ }^{+}-\mathrm{N}^{-} \mathrm{NO}_{2}{ }^{-}-\mathrm{N}$ ratio leading to highest TN removal as well as corresponding microbial composition of the biofilm and accompanying $\mathrm{SCN}^{-}$removal efficiency (Scenario 2). 


\section{Highlights}

A complete thiocyanate-based autotrophic denitrification (AD) model was developed.

Thiocyanate-based AD model was evaluated with integration of Anammox model.

Relationship between thiocyanate and $\mathrm{NH}_{4}{ }^{+}-\mathrm{N}^{-} \mathrm{NO}_{2}{ }^{-} \mathrm{N}$ for maximum removal was studied. 
The authors declare no conflict of interest. 